\title{
An Analysis Of Business Process Outsourcing Strategies Of Public And Private Sector Banks In India
}

Siva Prasad Ravi, Thompson Rivers University, Canada

Ravi Kumar Jain, Symbiosis International University, India

Hari P. Sharma, Virginia State University, Petersburg, USA

\begin{abstract}
This paper is a study of the recent trends of Business Process Outsourcing (BPO) strategies and practices among banking institutions in India. The study attempts to analyze BPOs used by private and public banks using four dimensional descriptive conceptual dimensions of outsourcing: 1) shoring model (vendor location/service creation), 2) sourcing model (vendor type), 3) engagement model (number of vendors engaged), and 4) duration of the engagement (contract period). The comparison of results reveals similar trends of outsourcing for public and private banks. However, public banks are more regulated, and thus are restricted from outsourcing of certain processes to avoid excessive risks of privacy of data and information related to customers. From a financial strategic point of view, in the long run, the underlying profit margins of a public bank might have adverse effects.
\end{abstract}

Keywords: Business Processes; Banking Industry; Outsourcing Strategy; Engagement model; Customization; Public sector banks; Private Sector Banks; Horizontal Activities; Vertical Activities

\section{INTRODUCTION}

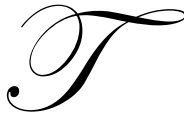

he concept of industrialization; i.e. the segregation of formerly tightly integrated value chains, has been around for several years now in the banking industry. Although banks and financial institutions globally have devoted substantial efforts and resources toward re-organization and restructuring of their value chains, an industry-wide paradigmatic transition toward distributed value chains has not yet fully occurred (Gellrich, et al. 2005). However, the emergence of outsourcing as a business practice, coupled with a deeper penetration of Information and Communication Technology (ICT) in banks, is changing this landscape gradually.

The justification for outsourcing activities, such as cash management, research and business analytics, and other processes that otherwise are considered core to the banking business, lies in the argument that these activities, though essential to the bank, do not provide a unique competitive advantage. This implies that those activities, where a bank can do better than its competitors, and which generates a competitive advantage, are retained in house and the rest are outsourced (Chris, et al. 2004). The outsourcing strategy has shifted from product (and/or service) focus to that of differentiation and speed-to-market. Several studies pertaining to outsourcing in the financial services sector show a gradually growing trend in outsourcing, both in terms of nature and scope of activities outsourced, and also emphasize that outsourcing is a critical aspect of financial institutions to survive in today's business environment (Federal Bank of New York, 1999).

The purpose of this research paper is to analyze business process outsourcing strategies for private and public banks in India and implications on the profitability of the banks. 


\section{REVIEW OF LITERATURE}

Both in practice and literature, various dimensions of outsourcing have been identified as: 1) shoring model (vendor location/service creation), 2) sourcing model (vendor type), 3) engagement model (number of vendors engaged), and 4) duration of the engagement (contract periods). Fröschel (1999) proposes two broad categories of outsourcing; namely, IT outsourcing and business process outsourcing. The first category comprises all the IT-related activities, both the IT infrastructure and the IT applications. The second category includes all the business processes. Further, the study highlights that both these categories can encompass different activities, such as development, operations, maintenance, care, customization and further development.

The ownership of the outsourcing facility and the transfer of assets is also an important dimension of outsourcing. Dibbern and Heinzl (2001), for example, distinguish between the procurement of a service from a legally independent entity (third-party vendor) and from profit centers with capital ties to the enterprise (e.g. subsidiary or joint venture). Another important dimension of outsourcing is the number of vendors engaged by a client (Lacity and Hirschheim, 1995; Lacity and Willcocks, 2001). An organization may choose to engage a single vendor (single outsourcing) for all its outsourcing needs or may engage multiple vendors for the same (multiple outsourcing) depending upon several factors, like nature of the activities, vendor's capabilities, client's ability to manage vendors, availability of vendors, and maturity of outsourcing market, and so on. Similarly, Gallivan and Oh (1999) analyzed various IT outsourcing relationships as business alliances and described client vendor relationship (single client/single vendor, multiple clients/single vendor and so on) and highlighted that these simple relationships may prove to be risky for the client due to the dependency on single vendor. Cross (1995) observed, at British Petroleum, that engaging single vendor poses a serious risk of vendor dependency, especially in an immature outsourcing market, and hence, it is prudent for the organizations to consider engaging multiple vendors for outsourcing.

The scope or the extent of outsourcing is also a very important dimension of an outsourcing decision. Albright (2003), Lacity and Hirschheim (1995), and Lacity and Willcocks (2001) use the terms 'total' and 'selective outsourcing' describing the coverage or scope of the outsourced services. In a total outsourcing arrangement, a client outsources a complete activity or a business process or an entire function, while in selective outsourcing, the client procures services from the vendors only partially. In this context, the vendors are normally third-party external vendors. Brawn and Winter (2005) have developed a conceptual framework of the outsourcing phenomenon by studying four dimensions of outsourcing; namely, outsourcing components (IT or business process), nature of activities (maintenance or development activities), service individualization (shared service or customization) and degree of independence (external or captive service provider).

As the outsourcing practice was getting widely adopted across several industries and geographies, coupled with the maturing of the vendor market and the outsourcing services being offered in a variety of packages, several new sourcing models have emerged during the late 1990s. Willcocks and Lacity (1998) describe six forms of the emerging models of outsourcing - value-added outsourcing, equity holding, multi-sourcing, co-sourcing, spin-offs, and creative contracting. Similarly, some studies describe different models of outsourcing based on the number of vendors engaged. For instance, Gallivan and Oh (1999) have described four outsourcing models; namely, Dyadic outsourcing arrangement, multi-vendor, co-sourcing, and complex sourcing.

\section{RESEARCH OBJECTIVES AND HYPOTHESIS}

This study examines the current practices pertaining to BPO among scheduled commercial banks ${ }^{1}$ in India. It makes a comparison between public and private sector banks with respect to their outsourcing practices with reference to four dimensions of outsourcing; namely, model of outsourcing, vendor type, engagement model and contract period.

\footnotetext{
${ }^{1}$ Scheduled commercial Banks constitute those banks which have been included in the Second Schedule of Reserve Bank of India(RBI) Act, 1934. The schedule includes only those banks that satisfy the criteria laid down by RBI vide section 42 (6) (a) of the Act. Being a part of the second schedule confers some benefits to a bank in terms of access to RBI's support, especially during the times of liquidity constraints. This status also subjects a bank to abide by certain conditions and obligation towards the reserve regulations of RBI.
} 
With these objectives, the following hypotheses were formulated and tested.

$\mathbf{H}_{1}$ : $\quad$ There is no significant difference among the public sector and private sector banks in their BPO practices with respect to the preference of the 'model of outsourcing'.

$\mathbf{H}_{2}$ : There is no significant difference among the public sector and private sector banks in their BPO practices with respect to the preference of the 'vendor type'.

$\mathbf{H}_{3}$ : $\quad$ There is no significant difference among the public sector and private sector banks in their BPO practices with respect to the preference of the 'engagement model'.

$\mathbf{H}_{4}$ : here is no significant difference among the public sector and private sector banks in their BPO practices with respect to the preference of the 'contract period'.

\section{RESEARCH METHODOLOGY}

The multi-level stratified sampling method was used for sample selection of the study. Of a total of 63 scheduled commercial banks (Annexure: A), which includes eight new private sector banks (before the takeover of Centurion Bank of Punjab by HDFC Bank in the month of May, 2008) $)^{2}, 16$ old private sector banks, 28 public sector banks (including SBI and its subsidiaries, and IDBI), and 11 Foreign banks, a sample of 30 banks was selected for the study. This sample represents 47 percent of the universe, and further, they disburse nearly 80 percent of the loans made by all scheduled commercial banks in India.

Further, a list of widely outsourced business activities by banks and financial institutions globally is prepared after reviewing the available literature on outsourcing. These activities are then broadly grouped into two categories - 'horizontal business activities' and 'vertical business activities'. Horizontal business activities are those that are common across organizations, irrespective of the industry they belong to. Vertical activities are those that are specific to a particular business and industry. The list of activities thus identified was subjected to further screening using panel discussions involving senior bank managers and outsourcing vendors to make it suitable to the context of the Indian banking industry (Annexure: B). Further, various models of outsourcing, vendor types, engagement models and contract periods prevalent in the industry are also identified, screened and selected (Annexure: $\mathrm{C}$ ).

\section{Tools used for Data Analysis}

Inferential analysis has been carried out by using statistical tools like t-test and chi-square (test of association) test. To test the hypotheses, chi-square test is used. While using chi-square test, Yates correction is applied to all those contingency tables where the expected frequency in one or more cells was less than 5.

\section{DATA ANALYSIS AND RESULTS}

\section{Horizontal Business Activities Outsourced by the Banks}

The value of $\mathrm{t}$ is conspicuous from the industry trends and the literature on outsourcing that states a significant portion of activities that are outsourced globally by different organizations across different industries in different countries, are horizontal business activities, e.g., customer care, payroll, recruitment, training and development, etc. These are basically supporting activities that are common across industries independent of the nature of the business of an organization. However, the study brings out some striking revelations (Table 1) about the outsourcing practices among banks in India. It is observed that both public and private sector banks have serious reservations in outsourcing their horizontal business activities. 75 percent of public sector banks and 70 percent of the private sector banks have preferred not to outsource their customer care and technical help desk activities.

\footnotetext{
${ }^{2}$ Press release. "HDFC Bank and Centurion Bank of Punjab Receive RBI Approval for Merger", http://www.centurionbop.co.in/news/press_20_05_2008.pdf (accessed on 26 ${ }^{\text {th }}$ September, 2008).
} 
Further, for sales and marketing activities, it is observed that 80 percent of the public sector banks preferred not to outsource, while 60 percent of the private sector banks chose to outsource. A majority of banks preferred to retain the activities that involve direct dealing/interaction with the customer (e.g., sales, marketing, customer care etc.). While the private sector banks, with shortages of manpower, did not hesitate to outsource their sales and marketing activities to fuel aggressive growth plans, the majority of public sector banks preferred to retain sales and marketing activities in-house as this enables them to put their under-utilized manpower to productive use.

Table 1: Horizontal Business Activities Outsourced by the Banks

\begin{tabular}{|c|c|c|c|c|c|c|c|c|c|c|c|}
\hline \multirow[b]{2}{*}{$\begin{array}{c}\text { Name of the } \\
\text { Variable }\end{array}$} & \multicolumn{5}{|c|}{ Public Sector Banks } & \multicolumn{5}{|c|}{ Private Sector banks } & \multirow[b]{2}{*}{$t$ Value } \\
\hline & \begin{tabular}{|c|} 
Outsourced \\
$(\%)$
\end{tabular} & $\begin{array}{c}\text { Not } \\
\text { Outsourced }\end{array}$ & Mean & SD & Total & \begin{tabular}{|c|} 
Outsourced \\
$(\%)$
\end{tabular} & $\begin{array}{c}\text { Not } \\
\text { Outsourced }\end{array}$ & Mean & SD & Total & \\
\hline $\begin{array}{l}\text { Customer care/ } \\
\text { technical help desk }\end{array}$ & $\begin{array}{c}5 \\
(25) \\
\end{array}$ & $\begin{array}{c}15 \\
(75) \\
\end{array}$ & 1.75 & 0.444 & 20 & \begin{tabular}{|c|}
3 \\
$(30)$ \\
\end{tabular} & $\begin{array}{c}7 \\
(70) \\
\end{array}$ & 1.70 & 0.483 & 10 & 0.282 \\
\hline Sales and marketing & $\begin{array}{c}4 \\
(20) \\
\end{array}$ & $\begin{array}{c}16 \\
(80)\end{array}$ & 1.80 & 0.410 & 20 & $\begin{array}{c}6 \\
(60) \\
\end{array}$ & $\begin{array}{c}4 \\
(40) \\
\end{array}$ & 1.40 & 0.516 & 10 & $2.309 *$ \\
\hline $\begin{array}{l}\text { Data entry, } \\
\text { verification and } \\
\text { validation }\end{array}$ & $\begin{array}{c}6 \\
(30)\end{array}$ & $\begin{array}{c}14 \\
(70)\end{array}$ & 1.70 & 0.470 & 20 & $\begin{array}{c}6 \\
(60)\end{array}$ & $\begin{array}{c}4 \\
(40)\end{array}$ & 1.40 & 0.516 & 10 & 1.595 \\
\hline $\begin{array}{l}\text { Human resource } \\
\text { selection and } \\
\text { recruitment }\end{array}$ & $\begin{array}{c}3 \\
(15)\end{array}$ & $\begin{array}{c}17 \\
(85)\end{array}$ & 1.85 & 0.366 & 20 & $\begin{array}{c}1 \\
(10)\end{array}$ & $\begin{array}{c}9 \\
(90)\end{array}$ & 1.90 & 0.316 & 10 & -0.368 \\
\hline $\begin{array}{l}\text { Training and } \\
\text { development }\end{array}$ & $\begin{array}{c}0 \\
(0) \\
\end{array}$ & $\begin{array}{c}20 \\
(100) \\
\end{array}$ & 2.00 & 0.000 & 20 & $\begin{array}{c}1 \\
(10)\end{array}$ & $\begin{array}{c}9 \\
(90) \\
\end{array}$ & 1.90 & 0.316 & 10 & 1.440 \\
\hline $\begin{array}{l}\text { Payroll processing } \\
\text { and benefits } \\
\text { administration }\end{array}$ & $\begin{array}{c}1 \\
(5)\end{array}$ & $\begin{array}{l}19 \\
(95)\end{array}$ & 1.95 & 0.224 & 20 & $\begin{array}{c}6 \\
(60)\end{array}$ & $\begin{array}{c}4 \\
(40)\end{array}$ & 1.40 & 0.516 & 10 & $4.106^{*}$ \\
\hline \begin{tabular}{|l} 
Finance and \\
accounting services
\end{tabular} & $\begin{array}{c}0 \\
(0)\end{array}$ & $\begin{array}{c}20 \\
(100)\end{array}$ & 2.00 & 0.000 & 20 & $\begin{array}{c}1 \\
(10)\end{array}$ & $\begin{array}{c}9 \\
(90)\end{array}$ & 1.90 & 0.316 & 10 & 1.440 \\
\hline
\end{tabular}

A similar trend can be observed in the case of outsourcing of human resource recruitment, training and development, wherein 100 percent of public sector banks and 90 percent of private sector banks preferred not to outsource. Further, almost all banks preferred to retain recruitment, training and development of manpower inhouse, perhaps because banks already have their own well established staff training colleges and time tested and standardized recruitment, selection and training processes in place. Further, in case of public sector banks, the recruitment policy is bound by certain government policies (quotas and reservations, etc.) which may not be amenable to outsourcing.

It can also be inferred from the table that in case of finance and accounting activities, none of the banks, except for one private sector bank, preferred to outsource their activity. Several respondents have indicated that their banks are sensitive to accounting and financial figures and would not prefer to outsource such activities. However, some of the technology savvy banks have expressed no reservations of exploring the possibilities of outsourcing finance and accounting activities in the future. Similarly, in case of payroll and benefits administration activities, while 95 percent of the public sector banks have chosen not to outsource, 60 percent of the private sector banks responded affirmative to outsourcing. In the case of outsourcing of data entry, verification and validation activities, it is observed that 70 percent of the public sector banks did not outsource, while 60 percent of the private sector banks did outsource; and the remaining 40 percent private sector banks are willing to explore this option in the future.

The statistical analysis using t-statistics (Table 1) suggest that there is no statistically significant difference in the practices of public sector and private sector banks with respect to outsourcing of all horizontal business activities, except for two activities; namely, sales and marketing activities, as well as payroll and benefits administration services. 


\section{Vertical Business Activities Outsourced by the Banks}

Table 2: Vertical Business Activities Outsourced by the Banks

\begin{tabular}{|c|c|c|c|c|c|c|c|c|c|c|c|}
\hline \multirow[b]{2}{*}{ Name of the Variable } & \multicolumn{5}{|c|}{ Public Sector Banks } & \multicolumn{5}{|c|}{ Private Sector Banks } & \multirow[b]{2}{*}{$t$ Value } \\
\hline & $\begin{array}{c}\text { Outsourced } \\
(\%)\end{array}$ & $\begin{array}{c}\text { Not } \\
\text { Outsourced } \\
(\%)\end{array}$ & Mean & SD & Total & $\begin{array}{c}\text { Outsourced } \\
(\%)\end{array}$ & $\begin{array}{c}\text { Not } \\
\text { Outsourced } \\
(\%)\end{array}$ & Mean & SD & Total & \\
\hline $\begin{array}{l}\text { ATM cash } \\
\text { replenishment and } \\
\text { related activities }\end{array}$ & $\begin{array}{c}7 \\
(35)\end{array}$ & $\begin{array}{c}13 \\
(65)\end{array}$ & 1.65 & 0.489 & 20 & $\begin{array}{c}6 \\
(60)\end{array}$ & $\begin{array}{c}4 \\
(40)\end{array}$ & 1.40 & 0.516 & 10 & 1.296 \\
\hline $\begin{array}{l}\text { Cheque imaging, bills } \\
\text { and statements } \\
\text { printing }\end{array}$ & $\begin{array}{c}0 \\
(0)\end{array}$ & $\begin{array}{c}20 \\
(100)\end{array}$ & 2.00 & 0.000 & 20 & $\begin{array}{c}3 \\
(30)\end{array}$ & $\begin{array}{c}7 \\
(70)\end{array}$ & 1.70 & 0.483 & 10 & $2.828 *$ \\
\hline $\begin{array}{l}\text { Accounts/ loans/ } \\
\text { mortgage servicing }\end{array}$ & $\begin{array}{c}3 \\
(15)\end{array}$ & $\begin{array}{c}17 \\
(65) \\
\end{array}$ & 1.85 & 0.366 & 20 & $\begin{array}{c}4 \\
(40)\end{array}$ & $\begin{array}{c}6 \\
(60) \\
\end{array}$ & 1.60 & 0.516 & 10 & 1.535 \\
\hline $\begin{array}{l}\text { Credit/ debit/ private } \\
\text { label card services }\end{array}$ & $\begin{array}{c}8 \\
(40)\end{array}$ & $\begin{array}{c}12 \\
(60)\end{array}$ & 1.60 & 0.503 & 20 & $\begin{array}{c}4 \\
(40)\end{array}$ & $\begin{array}{c}6 \\
(60)\end{array}$ & 1.60 & 0.516 & 10 & 0.000 \\
\hline $\begin{array}{l}\text { Clearance and } \\
\text { payments processing }\end{array}$ & $\begin{array}{c}0 \\
(0)\end{array}$ & $\begin{array}{c}20 \\
(100)\end{array}$ & 2.00 & $0.000^{\mathrm{a}}$ & 20 & $\begin{array}{c}0 \\
(0)\end{array}$ & $\begin{array}{c}10 \\
(100)\end{array}$ & 2.00 & $0.000^{\mathrm{a}}$ & 10 & $* *$ \\
\hline Debt/ loan recovery & $\begin{array}{c}7 \\
(35) \\
\end{array}$ & $\begin{array}{c}13 \\
(65) \\
\end{array}$ & 1.65 & 0.489 & 20 & $\begin{array}{c}7 \\
(70) \\
\end{array}$ & $\begin{array}{c}3 \\
(30) \\
\end{array}$ & 1.30 & 0.483 & 10 & 1.854 \\
\hline $\begin{array}{l}\text { Reconciliation } \\
\text { services }\end{array}$ & $\begin{array}{c}1 \\
(5)\end{array}$ & $\begin{array}{c}19 \\
(95)\end{array}$ & 1.95 & 0.224 & 20 & $\begin{array}{c}0 \\
(0)\end{array}$ & $\begin{array}{c}10 \\
(100)\end{array}$ & 2.00 & 0.000 & 10 & -.701 \\
\hline Cash management & $\begin{array}{c}0 \\
(0)\end{array}$ & $\begin{array}{c}20 \\
(100)\end{array}$ & 2.00 & 0.000 & 20 & $\begin{array}{c}2 \\
(20)\end{array}$ & $\begin{array}{c}8 \\
(80) \\
\end{array}$ & 1.80 & 0.422 & 10 & $2.160 *$ \\
\hline Treasury management & $\begin{array}{c}0 \\
(0)\end{array}$ & $\begin{array}{c}20 \\
(100)\end{array}$ & 2.00 & $0.000^{\mathrm{a}}$ & 20 & $\begin{array}{c}0 \\
(0)\end{array}$ & $\begin{array}{c}10 \\
(100)\end{array}$ & 2.00 & $0.000^{\mathrm{a}}$ & 10 & $* *$ \\
\hline $\begin{array}{l}\text { Foreign exchange } \\
\text { management }\end{array}$ & $\begin{array}{c}0 \\
(0)\end{array}$ & $\begin{array}{c}20 \\
(100)\end{array}$ & 2.00 & $0.000^{\mathrm{a}}$ & 20 & $\begin{array}{c}0 \\
0 \\
(0)\end{array}$ & $\begin{array}{c}10 \\
(100)\end{array}$ & 2.00 & $0.000^{\mathrm{a}}$ & 10 & $* *$ \\
\hline $\begin{array}{l}\text { Fraud prevention and } \\
\text { anti-money laundering }\end{array}$ & $\begin{array}{c}1 \\
(5)\end{array}$ & $\begin{array}{c}19 \\
(95)\end{array}$ & 1.95 & 0.224 & 20 & $\begin{array}{c}1 \\
(10)\end{array}$ & $\begin{array}{c}9 \\
(90)\end{array}$ & 1.90 & 0.316 & 10 & 0.502 \\
\hline $\begin{array}{l}\text { Research, analytics } \\
\text { and business } \\
\text { intelligence }\end{array}$ & $\begin{array}{c}1 \\
(5)\end{array}$ & $\begin{array}{l}19 \\
(95)\end{array}$ & 1.95 & 0.224 & 20 & $\begin{array}{c}1 \\
(10)\end{array}$ & $\begin{array}{c}9 \\
(90)\end{array}$ & 1.90 & 0.316 & 10 & 0.502 \\
\hline
\end{tabular}

Figures in parenthesis show percentages. ** t-value cannot be computed as Std. error is Zero. *The difference is statistically significant.

As the outsourcing vendor market got matured and vendors gathered more experience in providing services for horizontal business processes, coupled with the increased severity of competition and margins getting thinner, the vendors ventured into offering specialized services for narrowly defined business activities that are specific to particular industries. Equity research, business analytics, treasury management, and clinical examination services etc., are some of the examples. These activities are called vertical activities in the outsourcing parlance.

It is observed (Table 2) that both public and private sector banks are conservative in outsourcing their vertical business processes. This is evident from the fact that none of the banks have outsourced high end banking activities such as clearance and payment services, reconciliation services, treasury management, and foreign exchange management services. It is also very evident that public sector banks are relatively more conservative in outsourcing vertical business processes. For instance, out of twelve vertical business activities considered for the study, five activities are not being outsourced by any of the public sector banks; and in the case of three activities, only one out of 20 banks has outsourced; and in case of the remaining four activities, more than 60 percent of the banks preferred not to outsource. However, in case of private sector banks, four activities are not being outsourced by any bank; in the case of two activities, only one out of ten banks have outsourced; and for the rest of the six activities, between 20 percent and 70 percent of the private sector banks have confirmed to have outsourced. 
A close observation of activity-wise outsourcing reveals that loan/debt recovery services and ATM cash replenishment-related activities are most favored for outsourcing by both public and private sector banks. Private sector banks showed more active outsourcing with 70 percent and 60 percent, respectively, for each of these activities, while the figure for the same is only 35 percent in case of public sector banks.

The next favored activity for outsourcing was credit/debit card services where 40 percent of both the public and private sector banks have responded positively, while a few of them expressed their willingness to outsource in the future, once they introduce credit/debit card services. The reason for favoring it for outsourcing can be attributed to the fact that the entire process cycle in card services involves multiple processing agencies and stakeholders (e.g., card providers like Master and Visa), and the entire process is digitally executed, making it amenable to outsourcing. Further, card services are specialized services that call for sophisticated IT infrastructure; hence, these services are often procured by banks as ready-to-use from third-party vendors.

All in all, the statistical analysis reveals that there is no significant difference among public and private sector banks in respect of their outsourcing practices pertaining to vertical business activities, except in the case of two services; namely, cash management and imaging and printing services. In both cases, private sector banks showed a more positive response than the public sector banks.

There is an absolute conservatism among banks, both public and private sector, in outsourcing business activities. This conservative approach may be due to management's attitude toward outsourcing; i.e., the managements of banks still do not perceive outsourcing as a prudent business practice, at least in the case of business activities. Another possible reason could be that the banks are not really prepared to outsource in terms of digitizing and standardizing their business processes. The reasons behind this conservatism in outsourcing business processes call for further investigation.

\section{Dimension 1: Model of Outsourcing}

Table 3: Model of Outsourcing by Bank Type

\begin{tabular}{|c|c|c|c|c|c|c|c|c|c|c|}
\hline \multirow{2}{*}{$\begin{array}{l}\text { Bank } \\
\text { Type }\end{array}$} & \multicolumn{3}{|c|}{ Horizonal Business Activities } & \multirow[b]{2}{*}{ Total } & \multirow{2}{*}{$\begin{array}{c}\text { Chi- } \\
\text { square } \\
\text { Value }\end{array}$} & \multicolumn{3}{|c|}{ Vertical Business Activities } & \multirow[b]{2}{*}{ Total } & \multirow{2}{*}{$\begin{array}{c}\text { Chi- } \\
\text { square } \\
\text { Value }\end{array}$} \\
\hline & $\begin{array}{c}\text { On- } \\
\text { shore }\end{array}$ & NearShore & Offshore & & & $\begin{array}{c}\text { On- } \\
\text { shore }\end{array}$ & NearShore & Offshore & & \\
\hline $\begin{array}{l}\text { Public } \\
\text { Sector }\end{array}$ & $\begin{array}{c}19 \\
(95) \\
\end{array}$ & $\begin{array}{c}1 \\
(5) \\
\end{array}$ & $\begin{array}{c}0 \\
(0) \\
\end{array}$ & $\begin{array}{c}20 \\
(100) \\
\end{array}$ & \multirow{3}{*}{$0.2396 * *$} & $\begin{array}{c}16 \\
(80) \\
\end{array}$ & $\begin{array}{c}4 \\
(20) \\
\end{array}$ & $\begin{array}{c}0 \\
(0) \\
\end{array}$ & $\begin{array}{c}20 \\
(100) \\
\end{array}$ & \multirow{3}{*}{$0.0243 * *$} \\
\hline $\begin{array}{l}\text { Private } \\
\text { Sector }\end{array}$ & $\begin{array}{c}8 \\
(80) \\
\end{array}$ & $\begin{array}{c}1 \\
(10)\end{array}$ & $\begin{array}{c}1 \\
(10)\end{array}$ & $\begin{array}{c}10 \\
(100)\end{array}$ & & $\begin{array}{c}7 \\
(70)\end{array}$ & $\begin{array}{c}3 \\
(30)\end{array}$ & $\begin{array}{c}0 \\
(0)\end{array}$ & $\begin{array}{c}10 \\
(100)\end{array}$ & \\
\hline Total & $\begin{array}{c}27 \\
(90) \\
\end{array}$ & $\begin{array}{c}2 \\
(7) \\
\end{array}$ & $\begin{array}{c}1 \\
\text { (3) }\end{array}$ & $\begin{array}{c}30 \\
(100)\end{array}$ & & $\begin{array}{c}23 \\
(77) \\
\end{array}$ & $\begin{array}{c}7 \\
(23) \\
\end{array}$ & $\begin{array}{c}0 \\
(0)\end{array}$ & $\begin{array}{c}30 \\
(100)\end{array}$ & \\
\hline
\end{tabular}

Figures in parenthesis show percentages. **There is no significant difference, at 95 percent significance level and 2 degrees of freedom.

As far as the model of outsourcing is concerned, it is very evident that banks, both in public and private sector, have preferred the 'On-shore' model over the other two models of outsourcing. Nearly 77 percent of the banks have chosen 'on-shore' outsourcing, while a mere 23 percent of them preferred the 'nearshore' outsourcing model with respect to vertical business activities. A similar pattern could be seen in the case of the outsourcing of horizontal business activities with 90 percent of the banks preferring 'on-shore' outsourcing model. It is also interesting to note that none of the banks preferred the 'offshore' outsourcing model, particularly when they outsourced their vertical business activities. Only one private sector bank has chosen offshore as preferred model for outsourcing their horizontal business activities (Table 3).

This pattern of preference skewed in favor of 'on-shore' outsourcing model can be due to the existence of a matured vendor market in India that promises to deliver high-quality services at an economical rate. India has the widest vendor base with a proven track record of delivering low-cost advantage and superior service quality - a combination of benefits which cannot be found anywhere else in the world. Moreover, with on-shore vendors, it is 
believed that the client's management can have the convenience of monitoring the vendor closely than that which is possible with nearshore or offshore vendors. Top managers at several banks have confirmed this as they expressed their preference to have the outsourcing vendors working on their premises (also called 'onsite' service provision in the outsourcing parlance) so that effective monitoring of the vendor becomes easier.

Further, the premise of offshore model of outsourcing is rooted in the very possibility of substantial cost saving for the organizations in developed countries by exploiting the labor arbitrage available in the developing countries. This labor arbitrage is possible due to a significant labor cost differential prevailing between the developed and the developing countries. However, this advantage may not apply for the banks operating in India as their vendors are also operating in India. Further, they may not find any better offshore location where they can expect a cost advantage, yet without compromising on service quality and control that justifies such a decision. The decision by a few banks to opt for offshore or nearshore outsourcing may be driven by their need to augment gaps in their technology and/or specific skill sets.

The analysis further reveals that the pattern of preference for outsourcing models is more or less the same among public and private sector banks. Ninety-five percent and 80 percent of the public sector banks preferred 'onshore' model for outsourcing horizontal and vertical activities, respectively. The corresponding figures for private sector banks are 70 and 80 percent for outsourcing horizontal and vertical activities, respectively. The statistic values (chi-square, $\left.\chi^{2}\right)$ in both cases - outsourcing of horizontal activities $\left(\chi^{2}=0.2396\right)$ and vertical activities $\left(\chi^{2}=\right.$ 0.0243 ) - shows that there is no significant difference among public and private sector banks with respect to their preference for the model of outsourcing.

\section{Dimension 2: Vendor Type}

Table 4: Model of Outsourcing by Vender Type

\begin{tabular}{|c|c|c|c|c|c|c|c|c|c|c|}
\hline \multirow{2}{*}{$\begin{array}{l}\text { Bank } \\
\text { Type }\end{array}$} & \multicolumn{3}{|c|}{ Horizontal Business Activities } & \multirow[b]{2}{*}{ Total } & \multirow{2}{*}{$\begin{array}{c}\text { Chi- } \\
\text { square } \\
\text { Value }\end{array}$} & \multicolumn{3}{|c|}{ Vertical Business Activities } & \multirow[b]{2}{*}{ Total } & \multirow{2}{*}{$\begin{array}{c}\text { Chi- } \\
\text { square } \\
\text { Value }\end{array}$} \\
\hline & Captive & $\begin{array}{c}\text { Joint } \\
\text { Venture }\end{array}$ & $\begin{array}{l}\text { Third- } \\
\text { party }\end{array}$ & & & Captive & $\begin{array}{c}\text { Joint } \\
\text { Venture }\end{array}$ & $\begin{array}{l}\text { Third- } \\
\text { party }\end{array}$ & & \\
\hline $\begin{array}{l}\text { Public } \\
\text { Sector }\end{array}$ & $\begin{array}{c}5 \\
(25) \\
\end{array}$ & $\begin{array}{c}0 \\
(0) \\
\end{array}$ & $\begin{array}{c}15 \\
(75) \\
\end{array}$ & $\begin{array}{c}20 \\
(100)\end{array}$ & \multirow{3}{*}{$0.1552 * *$} & $\begin{array}{c}6 \\
(30) \\
\end{array}$ & $\begin{array}{c}0 \\
(0) \\
\end{array}$ & $\begin{array}{c}14 \\
(70) \\
\end{array}$ & $\begin{array}{c}20 \\
(100) \\
\end{array}$ & \multirow{3}{*}{$0.1786^{* *}$} \\
\hline $\begin{array}{l}\text { Private } \\
\text { Sector }\end{array}$ & $\begin{array}{c}2 \\
(20)\end{array}$ & $\begin{array}{c}1 \\
(10)\end{array}$ & $\begin{array}{c}7 \\
(70)\end{array}$ & $\begin{array}{c}10 \\
(100)\end{array}$ & & $\begin{array}{c}3 \\
(30)\end{array}$ & $\begin{array}{c}0 \\
(0)\end{array}$ & $\begin{array}{c}7 \\
(70)\end{array}$ & $\begin{array}{c}10 \\
(100)\end{array}$ & \\
\hline Total & $\begin{array}{c}7 \\
(23)\end{array}$ & $\begin{array}{c}1 \\
(3)\end{array}$ & $\begin{array}{c}22 \\
(73)\end{array}$ & $\begin{array}{c}30 \\
(100)\end{array}$ & & $\begin{array}{c}9 \\
(30)\end{array}$ & $\begin{array}{c}0 \\
(0)\end{array}$ & $\begin{array}{c}21 \\
(70)\end{array}$ & $\begin{array}{c}30 \\
(100)\end{array}$ & \\
\hline
\end{tabular}

Figures in parenthesis show percentages. **There is no significant difference, at 95 percent significance level and 2 degrees of freedom.

It is observed that nearly 73 and 70 percent of all the banks surveyed in the study have preferred 'thirdparty' vendor type for outsourcing their horizontal business activities and vertical activities, respectively (Tables 5 \& 6). Further, 23 percent and 30 percent of the banks preferred captive vendor type in case of outsourcing their horizontal and vertical business activities, respectively, and few banks preferred joint venture arrangements. By and large, the third-party vendor type has emerged as the most preferred vendor type in case of outsourcing, irrespective of the nature of activity being outsourced. Joint venture vendor type has been the least preferred vendor type among the banks in India. It is interesting to note that $25-30$ percent of the public sector banks, especially bigger ones, have chosen to have their own captive vendors for outsourcing both type of business activities. Similarly, in case of outsourcing business activities, even private sector banks, preferred to have captive vendors rather than engaging in joint ventures (Table 4). This pattern of preference for captive vendors by public sector banks can be due to the size and scale of operations of some the public sector banks (e.g., SBI, Canara Bank, etc.) which justifies setting up of captive services center.

It is also observed that a few respondents preferred a combination of both captive and third-party or joint venture and third-party vendor types, depending on the nature of the services required and the degree of control the management wanted to exercise on the vendor. The inclination to have more control on outsourcing vendors reflects 
the conservative nature of public sector banks. However, many of them didn't have any choice but to engage thirdparty vendors owing to the constraints of size and scope of activities, as well as limited financial and technical abilities to justify having a captive center or a joint venture. Hence, the majority of them had to choose third-party service providers for outsourcing their business activities.

A close look into the figures reveals that 70 to 75 percent of public sector banks preferred third-party vendor as compared to 25 to 30 percent who preferred captive and few that preferred joint venture vendor types. The trend is the same among the private sector banks with 70 to 80 percent of them preferring third-party vendors compared to 20 to 30 percent who preferred captive vendor types and a few preferred joint venture vendor types. The chi-square statistic values $\left(\chi^{2}\right)$ suggest a similar pattern of outsourcing practices among public and private sector banks in India in terms of the preference for vendor types in both cases - horizontal activities $\left(\chi^{2}=0.1552\right)$ and vertical activities $\left(\chi^{2}=0.1786\right)$.

The preference for third-party vendors is more pronounced, especially when developing in-house capabilities involve more time, money and managerial resources, while the same services can be availed in substantially lesser time and at a relatively lower cost from the matured vendors with superior competencies. Further, it also relieves management to focus on the core business, while leaving the non-core activities to the specialists. Of course, there are a few conservative banks that preferred captive vendor type as they preferred having more control on the vendor and over their processes and did not mind having the additional burden of managing more people on their own, although as a separate legal entity. Some of the respondents expressed that by having a separate entity (a captive unit) for providing outsourcing services, banks can circumvent some of the ills of their permanent employment policy while retaining control over the vendor and on the outsourced activities.

\section{Dimension 3: Engagement Model}

Engagement model implies the number of vendors a client engages for outsourcing. A client can engage one or more vendors to procure one or more services.

Table 5: Engagement Model Preferred By Bank

\begin{tabular}{|c|c|c|c|c|c|c|c|c|c|c|}
\hline \multirow[b]{2}{*}{$\begin{array}{l}\text { Bank } \\
\text { Type }\end{array}$} & \multicolumn{3}{|c|}{ Horizontal Business Activities } & \multirow[b]{2}{*}{ Total } & \multirow{2}{*}{$\begin{array}{c}\text { Chi- } \\
\text { square } \\
\text { Value }\end{array}$} & \multicolumn{3}{|c|}{ Vertical Business Activities } & \multirow[b]{2}{*}{ Total } & \multirow{2}{*}{$\begin{array}{c}\text { Chi- } \\
\text { square } \\
\text { Value }\end{array}$} \\
\hline & $\begin{array}{c}\text { Single } \\
\text { Vendor }\end{array}$ & $\begin{array}{c}\text { Multiple } \\
\text { Vendor }\end{array}$ & $\begin{array}{c}\text { Multi- } \\
\text { sourcing }\end{array}$ & & & $\begin{array}{c}\text { Single } \\
\text { Vendor }\end{array}$ & $\begin{array}{l}\text { Multiple } \\
\text { Vendor }\end{array}$ & $\begin{array}{c}\text { Multi- } \\
\text { sourcing }\end{array}$ & & \\
\hline $\begin{array}{l}\text { Public } \\
\text { Sector }\end{array}$ & $\begin{array}{c}5 \\
(25) \\
\end{array}$ & $\begin{array}{c}14 \\
(70) \\
\end{array}$ & $\begin{array}{c}1 \\
(5) \\
\end{array}$ & & \multirow{3}{*}{$0.0875 * *$} & $\begin{array}{c}5 \\
(25) \\
\end{array}$ & $\begin{array}{c}14 \\
(70) \\
\end{array}$ & $\begin{array}{c}1 \\
(5) \\
\end{array}$ & $\begin{array}{c}20 \\
(100) \\
\end{array}$ & \multirow{3}{*}{$0.1370 * *$} \\
\hline $\begin{array}{l}\text { Private } \\
\text { Sector }\end{array}$ & $\begin{array}{c}3 \\
(30) \\
\end{array}$ & $\begin{array}{c}6 \\
(60) \\
\end{array}$ & $\begin{array}{c}1 \\
(10)\end{array}$ & & & $\begin{array}{c}2 \\
(20) \\
\end{array}$ & $\begin{array}{c}7 \\
(70) \\
\end{array}$ & $\begin{array}{c}1 \\
(10) \\
\end{array}$ & $\begin{array}{c}10 \\
(100)\end{array}$ & \\
\hline Total & $\begin{array}{c}8 \\
(26)\end{array}$ & $\begin{array}{c}20 \\
(67)\end{array}$ & $\begin{array}{c}2 \\
(7)\end{array}$ & & & $\begin{array}{c}7 \\
(23)\end{array}$ & $\begin{array}{c}21 \\
(70)\end{array}$ & $\begin{array}{c}2 \\
(7)\end{array}$ & $\begin{array}{c}30 \\
(100)\end{array}$ & \\
\hline
\end{tabular}

Figures in parenthesis show percentages. **There is no significant difference, at 95 percent significance level and 2 degrees of freedom.

Engaging a different vendor for every different type of activity outsourced; i.e., multiple vendor engagement model (which requires management to deal with multiple vendors at the organizational level) emerged as the most preferred vendor engagement model among both public and private sector banks with respect to the outsourcing of both horizontal and vertical business activities. It is observed that 67 to 70 percent of the banks surveyed preferred multiple vendor engagement model and 23 to 26 percent reported to prefer engaging single vendor for outsourcing their horizontal and vertical business activities, respectively. The remaining seven percent of the respondents preferred the multi-sourcing engagement model (Table 5). Thus, it is evident that, by and large, the multiple vendor engagement model remains a preferred choice among public and private sector banks with respect to outsourcing of their business activities.

It is interesting to note that despite the risk of vendor lock-ins, and the banks' management being aware of that, a few banks have expressed that they preferred dealing with a single vendor for all their outsourcing 
requirements or one vendor for every category of activities outsourced. Such preference can be attributed to two major reasons; namely, fear of novelty and problem of scarcity. Fear of novelty is due to the fact that it is new for most of the banks in India to adopt outsourcing as a business practice, and hence they prefer dealing with a lesser number of vendors in the initial days, which will help them understand and adapt to the initial challenges in managing outsourcing deals and outsourcing vendors.

On the contrary, the problem of scarcity is due to the fact that the business process outsourcing phenomenon being relatively new, vis-à-vis - IT outsourcing - in India, the vendor market for business-related services is not as matured as it is for the IT services. Therefore, it is very difficult to find a single vendor capable of providing a full range of services. Nevertheless, it is much easier to find several vendors for each category of activities, like human resources management, financial and accounting management, ATM management, printing and imaging services, business analytics, etc. Thus, the banks were prompted to engage one vendor for each activity they outsourced; in other words, choose multiple vendor engagement models. The above analysis and the chi-square statistic values, horizontal activities $\left(\chi^{2}=0.1552\right)$ and vertical activities $\left(\chi^{2}=0.1786\right)$, show that there is no significant difference among public and private sector banks with respect to their preference of engagement model for outsourcing their business activities.

\section{Dimension 4: Contract Period}

Another important dimension of outsourcing considered for the study is the 'contract period'; i.e., the duration of an outsourcing engagement. The three contract periods are defined as short-term (1-2 years), mediumterm (3-5 years), and long-term (5-10years) based on the duration of the contract.

Table 6: Contract Period Preferred by Banks

\begin{tabular}{|c|c|c|c|c|c|c|c|c|c|c|}
\hline \multirow[b]{2}{*}{$\begin{array}{l}\text { Bank } \\
\text { Type }\end{array}$} & \multicolumn{3}{|c|}{ Horizontal Business Activities } & \multirow[b]{2}{*}{ Total } & \multirow[b]{2}{*}{$\begin{array}{c}\text { Chi- } \\
\text { square } \\
\text { Value }\end{array}$} & \multicolumn{3}{|c|}{ Vertical Business Activities } & \multirow[b]{2}{*}{ Total } & \multirow[b]{2}{*}{$\begin{array}{c}\text { Chi- } \\
\text { square } \\
\text { Value }\end{array}$} \\
\hline & $\begin{array}{c}\text { Short } \\
\text { Term } \\
\text { 1-2 } \\
\text { Years }\end{array}$ & $\begin{array}{l}\text { Medium } \\
\text { Term } \\
\text { 3-5 Years }\end{array}$ & $\begin{array}{c}\text { Long } \\
\text { Term } \\
5- \\
\text { 10Years }\end{array}$ & & & $\begin{array}{c}\text { Short } \\
\text { Term } \\
1-2 \\
\text { Years }\end{array}$ & $\begin{array}{l}\text { Medium } \\
\text { Term } \\
\text { 3-5 Years }\end{array}$ & $\begin{array}{c}\text { Long } \\
\text { Term } \\
5- \\
\text { 10Years }\end{array}$ & & \\
\hline $\begin{array}{l}\text { Public } \\
\text { Sector }\end{array}$ & $\begin{array}{c}8 \\
(40) \\
\end{array}$ & $\begin{array}{c}10 \\
(50)\end{array}$ & $\begin{array}{c}2 \\
(10) \\
\end{array}$ & $\begin{array}{c}20 \\
(100) \\
\end{array}$ & \multirow{3}{*}{$4.1376^{* *}$} & $\begin{array}{c}8 \\
(40) \\
\end{array}$ & $\begin{array}{c}10 \\
(50)\end{array}$ & $\begin{array}{c}2 \\
(10) \\
\end{array}$ & $\begin{array}{c}20 \\
(100) \\
\end{array}$ & \multirow{3}{*}{$4.1376 * *$} \\
\hline $\begin{array}{l}\text { Private } \\
\text { Sector }\end{array}$ & $\begin{array}{c}0 \\
(0)\end{array}$ & $\begin{array}{c}9 \\
(90)\end{array}$ & $\begin{array}{c}1 \\
(10)\end{array}$ & $\begin{array}{c}10 \\
(100)\end{array}$ & & $\begin{array}{c}0 \\
(0)\end{array}$ & $\begin{array}{c}9 \\
(90)\end{array}$ & $\begin{array}{c}1 \\
(10)\end{array}$ & $\begin{array}{c}10 \\
(100)\end{array}$ & \\
\hline Total & $\begin{array}{c}8 \\
(27)\end{array}$ & $\begin{array}{c}19 \\
(63)\end{array}$ & $\begin{array}{c}3 \\
(10)\end{array}$ & $\begin{array}{c}30 \\
(100)\end{array}$ & & $\begin{array}{c}8 \\
(27)\end{array}$ & $\begin{array}{c}19 \\
(63)\end{array}$ & $\begin{array}{c}3 \\
(10)\end{array}$ & $\begin{array}{c}30 \\
(100)\end{array}$ & \\
\hline
\end{tabular}

Figures in parenthesis show percentages. **There is no significant difference, at 95 percent significance level and 2 degrees of freedom.

The majority of the banks - 63 percent - preferred medium-term contract periods while outsourcing business activities. Only 10 percent of all the banks preferred to have long-term contract periods for outsourcing business activities. It is also observed that while 40 percent of the public sector banks preferred short-term contract periods, none of the private sector banks preferred it. Similarly, while 50 percent of public sector banks preferred medium-term contracts, 90 percent of the private sector banks preferred it. Only 10 percent of the banks in both categories showed their preference for long-term contract periods (Table 6).

This clearly indicate that the medium-term contract period is the most preferred choice in outsourcing engagement, with respect to the outsourcing and irrespective of the nature of the activities being outsourced. However, it is interesting to note that a few public sector banks preferred to have a short-term contract period. This is due to the apprehensions about the efficacy of outsourcing as a business practice or may be because such business arrangements are new to them and hence, they wanted to try and test the vendor's ability to deliver the desired results for a short-term period before committing for a medium or long-term outsourcing engagement. 
Further, a few banks, by policy, do not commit for long-term contract periods. Further, contracts are mostly issued by calling tenders, and it is always preferred to have a contract period for a medium term of 3 to 5 years; otherwise, it will be very difficult to find a good vendor willing to take up the contract. Hence, the preference for a medium-term contract period is conspicuous among all the banks. Of course, there are a few banks that preferred long-term contract periods; however, it was especially for those banks where the service providers were their captive vendors.

Further, several banks, as directed by the corporate strategy and policy, do not commit to contracts for too long or too short a period. One, the outsourcing literature showed failure of long-term outsourcing contracts on several occasions, hence it is a common place for organizations not to prefer long-term contract unless it is an arrangement with a captive or joint venture vendors. Two, banks in India being conservative, especially the public sector banks, would want to experience the process of outsourcing and all its aspects so that they can be comfortable before committing to long- or medium-term contract periods.

The chi-square $\chi^{2}$ statistic values, in both cases, horizontal activities $\left(\chi^{2}=4.1376\right)$ and vertical activities $\left(\chi^{2}\right.$ $=4.1376$ ) shows that there is no significant difference among public and private sector banks with respect to their preference of contract period for outsourcing their business activities.

\section{CONCLUSION}

The analysis suggests that the majority of banks in India, both public and private sector, are outsourcing business-related activities. However, public sector banks are behind in outsourcing activities in comparison to private banks because of government regulations that have imposed restrictions for avoiding risks related to data security and data confidentiality. Private sector banks, to combat the competition, have adopted more aggressive strategies with respect to outsourcing of business activities. Most of the banks chose to outsource basic business activities, such as data entry, verification and validation, credit/debit cards services, etc, but only a few banks outsourced the advanced business-related activities, like cash management, treasury management, foreign exchange management, etc. Further, several public banks even expressed their reservation in outsourcing those business activities which involved customer interaction and those related to human resource training and development. The reasons for the same are the existence of sufficient in-house facilities and standardized practices, as well as policy guidelines of RBI, on outsourcing by banks.

It is also observed that almost all banks preferred having on-shore outsourcing irrespective of the type of activities outsourced. This could be due to the existence of a matured vendor market which promises delivery of quality services at most economical rates in India. Moreover, it is convenient to monitor on-shore vendors closely. It is interesting to note that the majority of banks preferred to engage third-party vendors for outsourcing engagements, although there were a few public sector banks that preferred having their own captive vendors for a purpose. The shortage of in-house resources and capabilities, on one hand, and the existence of a competitive vendor market, on the other, have prompted banks to choose third-party vendor types as the preferred model for outsourcing. Further, outsourcing to a third-party vendor relieves the banks to focus on their core competencies, while leaving the other activities for the specialists to do on their behalf.

It is also noticed that the majority of banks preferred dealing with a single vendor for providing all services - and in some case, one vendor for each activity - for outsourcing business-related activities. The reason for this is that it is new for the banks to adopt outsourcing as a business practice; hence, they prefer dealing with fewer vendors in the initial days, which will enable a better understanding of, and adaptation to, the initial challenges of outsourcing. Another noteworthy observation is that the medium-term contract periods of three to five years have been the most preferred choices for outsourcing, irrespective of the type of activities outsourced. Several public sector banks, however, preferred short-term contract periods, especially for outsourcing business-related activities. The reasons for the same are rooted in the banks' policies and practices related to awarding contracts to apprehensions due to the novelty of outsourcing as a business practice for their organizations. Further, there were a few banks that preferred long-term contract periods, but that was especially in those cases where the service providers were captive vendors (the bank's own subsidiary) of the bank. Overall, it can be inferred from the above analysis that the statistical evidence does not show any significant difference in the outsourcing strategies and 
practices of private sector banks vis-à-vis public sector banks in India with respect to all the dimensions considered for this research, with a few exceptions as discussed above. The authors believe that the banks are competing in order to minimize their costs by outsourcing. However, authors express their opinions that if public banks don't compete with private banks due to regulatory restrictions, public banks will incur a higher cost of operations and, of course, underlying profitability will go down. Therefore, futures research should focus on assessing financial impact as well as risks of outsourcing on private and public banks.

\section{AUTHOR INFORMATION}

Dr. Siva Prasad Ravi is an Assistant Professor at School of Business and Economics, Thompson Rivers University, Kamloops, BC, Canada.

Ravi Kumar Jain is an Assistant Professor at Symbiosis Institute of Research and Innovation, Symbiosis International University, India.

Hari Sharma is tenured Associate Professor of Finance at Virginia State University. His prior accomplishments include Vice President, Bank of America and Computer Programmer, Life Insurance Corporation of India.

\section{REFERENCES}

1. Ackermann, M. (2003). "Banks' Major Users, Providers in 1Q of Outsourced Services", American Banker, issue $75, \mathrm{p} 6$, http://www.americanbanker.com/article.html?id=20030417DICGJAED\&queryid=729607634\&hitnum=1

2. Albright, C. (2003). "Getting outsourcing right: Here are lessons from the biggest deals of what to do and what not to do," The Chief Executive, Montvale.

3. Braun, C., and Winter, R. (2005)."Classification of Outsourcing Phenomena in Financial Services," Proceedings of the 13th European Conference on Information Systems, Regensburg, http://web.iwi.unisg.ch/org/iwi/iwi_pub.nsf/wwwPublRecentGer/F0357B5EA5791833C12570AE00501B0 4/\$file/145_paper.pdf

4. Chris, O. Odindo., Stephen, Diacon., and Christine, Ennew. (2004). “Outsourcing in the UK Financial Services Industry: The Asian Offshore Market," Center For Risk and Insurance Studies (CRIS), discussion paper series 2004-I, Financial Services Research Forum, Nottingham University Business School, http://www.nottingham.ac.uk/business/cris/papers/2004-1.pdf Cross, J. (1995). "IT Outsourcing: British Petroleum," Harvard Business Review, May-June, pp.94-102.

5. Dibbern, J., and Heinzl, A. (2001). "Outsourcing der Informationsverarbeitung im Mittelstand: Test eines multitheoretischen Kausalmodells," Wirtschaftsinformatik, vol.43, no.4, pp.339-350.

6. Fröschel, F. (1999). "Vom IuK-Outsourcing zum Business Process Outsourcing," Wirtschaftsinformatik, vol.41, pp.458-460.

7. Gallivan, M.J. and Oh, W. (1999). “Analyzing IT outsourcing relationship as alliances among multiple clients and vendors", "proceedings of the $32^{\text {nd }}$ Annual Hawaii International Conference on Systems Sciences, HICSS-32, vol.7, p.7066, Hawaii.

8. Gellrich, T., Hackethal, A., and Holzhäuser, M. (2005). "Vertical Integration and Bank Performance," Proceedings of the Wirtschaftsinformatik, Bamberg, Germany.

9. Lacity, M. and Willcocks, L.P. (2001). Global Information Technology Outsourcing - In Search of Business Advantage. John Wiley \& Sons, Chichester.

10. Lacity, M., and Hirschheim, R. (1995). Beyond the Information Systems Outsourcing Bandwagon. John Wiley \& Sons, Chichester.

11. Lacity, M.C., and Willcocks, L. P. (1998). “An Empirical Investigation of Information Technology Sourcing Practices: Lessons From Experience,” MIS Quarterly, vol. 22, no.3, September, pp.363-408.

12. Press release. "HDFC Bank and Centurion Bank of Punjab Receive RBI Approval for Merger", http://www.centurionbop.co.in/news/press_20_05_2008.pdf

13. "Outsourcing Financial Services Activities: Industry Practices to Mitigate Risks," Federal Bank of New York, October, 1999, http://www.newyorkfed.org/banking/circulars/outsource.pdf 


\section{NOTES}

